\title{
Dissipation of Fluopyram and Tebuconazole Residues in/on Pomegranate and Soil in Western Maharashtra
}

\author{
Chidanand Shivshankar Patil1, Shashi Vemuri², Haidas Vitthal Deore1, \\ Yogesh Subhash Saindane ${ }^{1}$, Kosnam Kavitha ${ }^{2}$, Vodur Anitha ${ }^{2}$
}

${ }^{1}$ AINP on Pesticide Residues, Department of Agricultural Entomology, Mahatma Phule Krishi Vidyapeeth, Rahuri, Maharashtra, India

${ }^{2}$ AINP on Pesticide Residues, Professor Jayshankar Telangana State Agriculture University, Hyderabad, India

Email: cspatils@rediffmail.com,sash_3156@yahoo.co.in

How to cite this paper: Patil, C.S., Vemuri, S., Deore, B.V., Saindane, Y.S., Kavitha, K. and Anitha, V. (2018) Dissipation of Fluopyram and Tebuconazole Residues in/on Pomegranate and Soil in Western Maharashtra. Open Access Library Journal, 5: e4913.

https://doi.org/10.4236/oalib.1104913

Received: September 17, 2018

Accepted: November 16, 2018

Published: November 19, 2018

Copyright $\odot 2018$ by authors and Open Access Library Inc.

This work is licensed under the Creative Commons Attribution International License (CC BY 4.0).

http://creativecommons.org/licenses/by/4.0/

\begin{abstract}
Field and laboratory experiments were conducted to study the residues and dissipation of Fluopyram, a succinate dehydrogenase inhibitor (SDHI) and tebuconazole, demethylation inhibitor (DMI) used for the control of powdery mildew and Anthracnose diseases in grape. Residues of fluopyram dissipated with a half life of 4.04 and 5.18 days, at recommended and double dose, respectively. For tebuconazole, the half life values recorded were 4.75 and 5.42 days, respectively. The residues reached below quantification limit (BQL) on $10^{\text {th }}$ and $15^{\text {th }}$ day, in both the fungicides at recommended and double the recommended dose, respectively, which suggests a Pre-Harvest Interval (PHI) of 7.76 and 9.91 days for fluopyram and tebuconazole, respectively when applied at $75 \mathrm{~g}$ a.i./ha and $150 \mathrm{~g}$ a.i./ha.
\end{abstract}

\section{Subject Areas}

Entomology

\section{Keywords}

Fluopyram, Tebuconazole, Residues, Persistence, QuEChERS

\section{Introduction}

Pomegranate (Punica granatum) also called as "fruit of paradise" is one of the major fruit crops grown in tropical and subtropical regions of the world. The pomegranate fruit is known for its cool, refreshing juice and valued for its medicinal properties. In India, it is cultivated over an area of about 19,689 ha with a 
production of 230,644 MT [1]. Maharashtra is the leading producer of pomegranate followed by Karnataka, Andhra Pradesh, Gujarat and Tamil Nadu. Insect pests and diseases are the major constraints in the pomegranate cultivation. Shoot and fruit borer (Deudorix isocrates), thrips (Rhiphiphorothrips cruentatus) and aphids (Aphis punicae) are the major insects which cause severe damage to pomegranate Of late, this crop is under threat due to number of serious diseases such as bacterial blight (Xanthomonas axonopodis pv. punicae), wilt (Ceratocystis fimbriata), anthracnose (Colletotrichumgloeosporioides) and leaf spot and fruit rot (Alternaria alternata, Cercospora sp., Pseudocercospora sp., Drechslera sp. and Sphaceloma sp. etc.). Farmers rely heavily on synthetic pesticides for the control of insect pests and diseases in pomegranate.

However there are no insecticides and fungicides with label claim for use in pomegranate except cyantraniliprole $10.26 \%$ OD, quinalphos $25 \%$ EC, difenoconazole $25 \%$ EC, kitazin $48 \%$ EC, propineb $70 \%$ WP and metiram $55 \%+$ pyraclostrobin 5\% WG. [2]. Sometimes pesticides are applied even during fruiting stage. Indiscriminate use of pesticides has resulted in the accumulation of pesticide residues in the primary agricultural products as well as soil [3].

Luna Experience is a combination of fluopyram and tebuconazole and offers two different modes of action. Fluopyram, a tebuconazole broad spectrum fungicide belongs to a new chemical class. It is a succinate dehydrogenase inhibitor (SDHI) and breaks the respiration chain in the mitochondria of the fungus cell by blocking its energy production. Tebuconazole is a demethylation inhibitor (DMI). It interferes in the process of building structure of fungal cell wall. Finally, it inhibits the reproduction and further growth of fungus.

Fluopyram is a new fungicide and there is no data on its dissipation in pomegranate. Hence, studies were undertaken to validate the method for residue analysis of fluopyram and tebuconazole on liquid chromatography and mass spectrometry (LCMS) to determine the dissipation pattern of combination product, fluopyram and tebuconazole in pomegranate in western Maharashtra. The degradation or dissipation of insecticide is influenced by climatic conditions, type of application, plant species, dosage interval between application and time of harvest [4]. Hence it is necessary to determine the dissipation pattern of these two fungicides by following Good Agricultural Practices (GAP). Keeping this in view an attempt was made to conduct studies on the persistence of fluopyram, its metabolite and tebuconazole in/on pomegranate.

\section{Material and Methods}

\section{Chemicals and Reagents}

Analytical grade fluopyram (99.60\%), its metabolite fluopyram benzamide (99.40) and tebuconazole (95.60) as well as commercial formulation i.e. Luna Experience 400SC was provided by Bayer Crop Science Ltd., Mumbai. The solvents and sorbents used in extraction and analysis were distilled and checked for impurities prior to use. 


\section{Field experiment}

Residues and dissipation of fluopyram, its metabolite and tebuconazole in/on pomegranate and in soil was studied by conducting supervised field experiment during 2015 at the research farm of Mahatma Phule Krishi Vidyapeeth, Rahuri, Dist. Ahmednagar. During the period of investigation, the maximum and minimum temperature was 32.9 and 23.14 per cent. Humidity was 60.36 per cent. The experiment was conducted in RBD with three replications. Luna Experience $400 \mathrm{SC}$ was used at $75 \mathrm{~g}$ a.i./ha (X dose), $150 \mathrm{~g}$ a.i./ha (2X dose) along with untreated control. Two sprays of fluopyram $200+$ tebuconazole 200 (400 SC) were sprayed at an interval of 10 days initiating first spray at fruit setting stage. Water was sprayed in the control plot. Samples were collected periodically at $0,1,3,5$, $7,10,15$ and $20^{\text {th }}$ day after second spray. Third spray was given 15 days before harvest and mature fruits and soil samples were collected at harvest. About $1 \mathrm{~kg}$ immature fruits, $1 \mathrm{~kg}$ mature fruits and $1 \mathrm{~kg}$ of soil were collected from each treated plot. Collected samples were transported by keeping in dry ice and analysed at AINP on Pesticide Residues, PJTSAU, Hyderabad for the residues of fluopyram, its metabolite and tebuconazole by modified QuECHERS method [5].

\section{Residue analysis \\ Standard preparation}

An accurately weighed $10 \mathrm{mg}$ of an individual standard was dissolved in $10 \mathrm{ml}$ volumetric flask using suitable solvent to prepare the standard stock solution of $1000 \mathrm{mg} \mathrm{kg}^{-1}$. Standard stock solution of each insecticide was serially diluted to obtain intermediate lower concentration of $100 \mathrm{mg} \mathrm{kg}^{-1}$. They were stored in a refrigerator at $-40^{\circ} \mathrm{C}$. From the intermediate standards, working standards were prepared by suitably diluting the stock solution in n-hexane and used as standard check in analysis, linearity and recovery studies.

\section{Method validation}

Prior to analysis of samples, linearity of these fungicides was established on LCMS. Accuracy and precision of the method was determined by per cent mean recovery and per cent relative standard deviation. Linearity was studied by in jecting standard solution of fungicides under study at five linear concentrations i.e. $0.05,0.10,0.25,0.50,1.00 \mathrm{mg} \mathrm{kg}^{-1}$ in triplicate. The linearity curve was established with concentration of the standard and corresponding peak area. Recovery study was conducted in different matrices i.e. whole pomegranate fruit, edible arils, juice and cropped soil in order to establish the reliability of the method of analysis. For this purpose, pomegranate samples and soil from control plots were used. The samples were spiked with three different concentrations viz. 0.05 (LOQ), $0.25(5 \times \mathrm{LOQ})$ and $0.5(10 \times \mathrm{LOQ}) \mathrm{mg} \mathrm{kg}^{-1}$. The extraction and clean up were performed as described hereunder. Per cent recovery was calculated by using following formula.

$$
\text { Per cent recovery }=\frac{\text { Quantity of pesticide recovered }}{\text { Quantity of pesticide added }} \times 100
$$




\section{Extraction and clean up \\ Pomegranate fruits, Edible aril and Juice:}

The pomegranate immature fruits, edible aril and juice samples were analyzed for fluopyram, its metabolite-fluopyram benzamide and tebuconazole residues following the AOAC official method 2007.01 (QuEChERS) after validation of the method at the laboratory. The pomegranate fruits, edible aril and juice samples were homogenized separately with robot coupe blixer and homogenized $15 \pm 0.1$ g sample was taken in $50 \mathrm{ml}$ centrifuge tube. $30 \pm 0.1 \mathrm{ml}$ acetonitrile was added to sample tube. The sample was homogenized at 14,000 - 15,000 rpm for $2-3$ min using Heidolph silent crusher. $3 \pm 0.1$ g sodium chloride was added to sample, mixed thoroughly by shaking gently followed by centrifugation at 2500 $3000 \mathrm{rpm}$ for $3 \mathrm{~min}$ to separate the organic layer. The top organic layer of about $16 \mathrm{ml}$ was taken into $50 \mathrm{ml}$ centrifuge tube and added with $9 \pm 0.1 \mathrm{~g}$ anhydrous sodium sulphate to remove the moisture content. $8 \mathrm{ml}$ of extract was taken in to $15 \mathrm{ml}$ tube containing $0.4 \pm 0.01 \mathrm{~g}$ PSA sorbent (for dispersive solid phase d-SPE cleanup) and $1.2 \pm 0.01 \mathrm{~g}$ anhydrous magnesium sulphate. The sample tube was vortexed for $30 \mathrm{sec}$ then followed by centrifugation at $2500-3000 \mathrm{rpm}$ for $5 \mathrm{~min}$. The extract of about $1 \mathrm{ml}$ ( $0.5 \mathrm{~g}$ sample) was taken for analysis on LC-MS/MS under standard operational conditions.

Soil:

The soil samples were analyzed following the QuEChERS method after validation of the method at the laboratory. The soil samples were dried at room temperature under shade, ground, passed through $2 \mathrm{~mm}$ sieve and a representative $10 \mathrm{~g}$ sample was taken in to $50 \mathrm{ml}$ centrifuge tube. $20 \mathrm{ml}$ acetonitrile was added to sample tube and shaken vigorously for $2 \mathrm{~min}$. The samples were then added with $4 \pm 0.1 \mathrm{~g}$ magnesium sulphate and $1 \pm 0.1 \mathrm{~g}$ sodium chloride and centrifuged at $2500-3000 \mathrm{rpm}$ for $5 \mathrm{~min}$ to separate the organic layer. The top organic layer of about $10 \mathrm{ml}$ was taken into $15 \mathrm{ml}$ centrifuge tube and added with $250 \pm$ $0.1 \mathrm{mg}$ PSA sorbent and $1.5 \pm 0.01 \mathrm{~g}$ magnesium sulphate and sonicated for 1 min then centrifuged at $2500-3000 \mathrm{rpm}$ for $10 \mathrm{~min}$. The extract of about $1 \mathrm{ml}$ (0.5 g sample) was taken for analysis on LCMS/MS under standard operational conditions (Table $1 \&$ Table 2).

\section{Results and Discussion}

\section{Method validation}

The detector response to the neat standards of the fungicides was studied by injecting five linear concentrations of these fungicides. The graph was plotted with detector response against respective concentrations and linearity line was drawn. Figures 1-3 show that the response of the instrument was linear over the range tested and $\mathrm{R}^{2}$ value was 0.99 for all the fungicides under study. These results indicated that the LC-MS analysis is a valid method for residue determination of the tested fungicides in pomegranate fruits. Accuracy of the analytical method was determined by recovery studies. The per cent recovery was within 
acceptable range of 70 - 120 per cent prescribed by SANCO, 2011 [6] and mentioned in Table 3.

\section{Dissipation of insecticides}

Figures 4-7 show the dissipation pattern of fluopyram and tebuconazole (Table 4). Table 4 indicated that in immature pomegranate, initial residues of fluopyram were 0.219 and $0.395 \mathrm{mg} \mathrm{kg}^{-1}$ in recommended and double dose, respectively $2 \mathrm{~h}$

Table 1. LC-MS/MS parameters for fluopyram and tebuconazole.

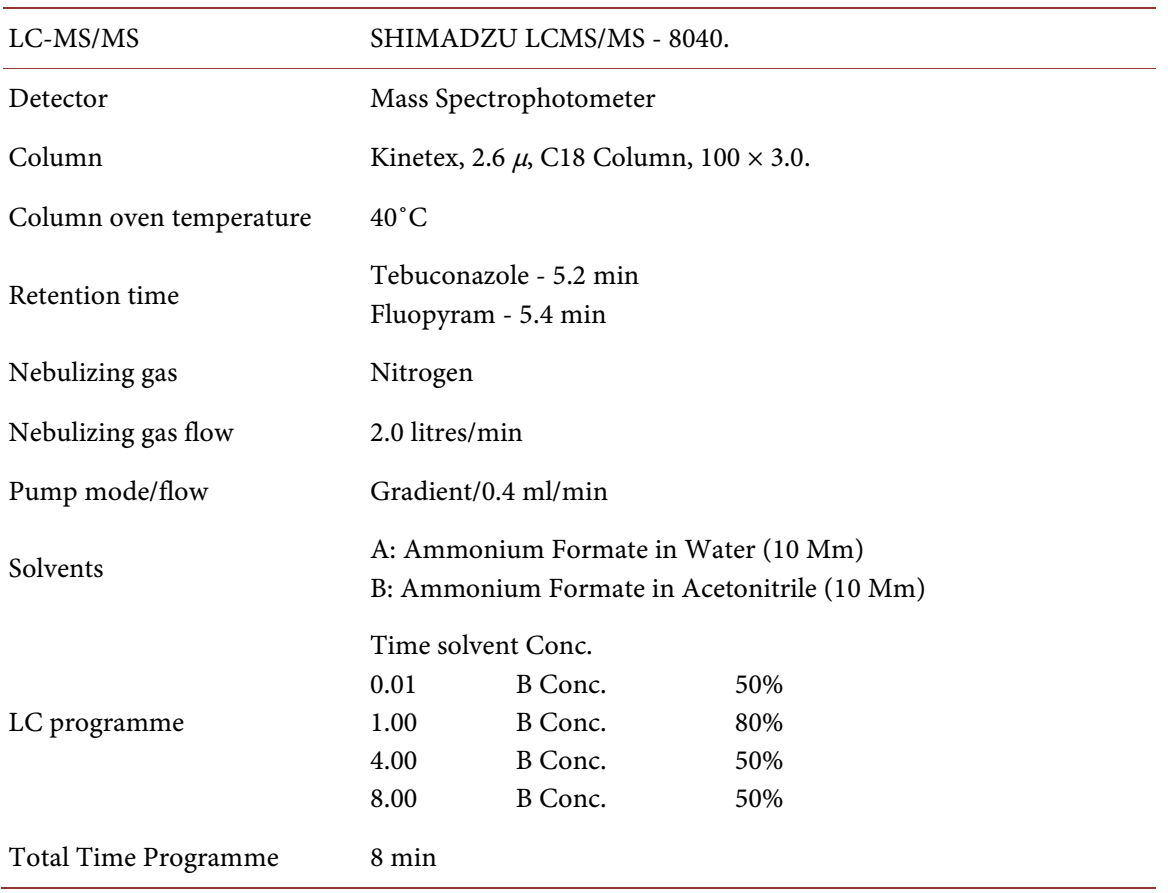

Table 2. LC-MS/MS parameters for fluopyram metabolite-fluopyram benzamide.

\begin{tabular}{|c|c|c|c|}
\hline LC-MS/MS & \multicolumn{3}{|c|}{ SHIMADZU LCMS/MS-8040. } \\
\hline Detector & \multicolumn{3}{|c|}{ Mass Spectrophotometer } \\
\hline Column & \multicolumn{3}{|c|}{ Kinetex, $2.6 \mu$, C18 Column, $100 \times 3.0$. } \\
\hline Column oven temperature & \multicolumn{3}{|l|}{$40^{\circ} \mathrm{C}$} \\
\hline Retention time & \multicolumn{3}{|c|}{ Fluopyram Benzamide $-1.5 \mathrm{~min}$} \\
\hline Nebulizing gas & \multicolumn{3}{|c|}{ Nitrogen } \\
\hline Nebulizing gas flow & \multicolumn{3}{|c|}{2.0 litres/min } \\
\hline Pump mode/flow & \multicolumn{3}{|c|}{ Gradient $/ 0.4 \mathrm{ml} / \mathrm{min}$} \\
\hline \multirow{2}{*}{ LC programme } & \multirow{2}{*}{\multicolumn{3}{|c|}{$\begin{array}{l}\text { A: Ammonium Formate in Water }(10 \mathrm{Mm})-40 \% \\
\text { B: Ammonium Formate in Methanol }(10 \mathrm{Mm})-60 \%\end{array}$}} \\
\hline & & & \\
\hline \multirow{5}{*}{ LC programme } & \multicolumn{3}{|c|}{ Time solvent Conc. } \\
\hline & 0.01 & B Conc. & $50 \%$ \\
\hline & 2.00 & B Conc. & $80 \%$ \\
\hline & 3.00 & B Conc. & $50 \%$ \\
\hline & 4.00 & B Conc. & $50 \%$ \\
\hline Total time programme & \multicolumn{3}{|c|}{$4 \mathrm{~min}$} \\
\hline
\end{tabular}




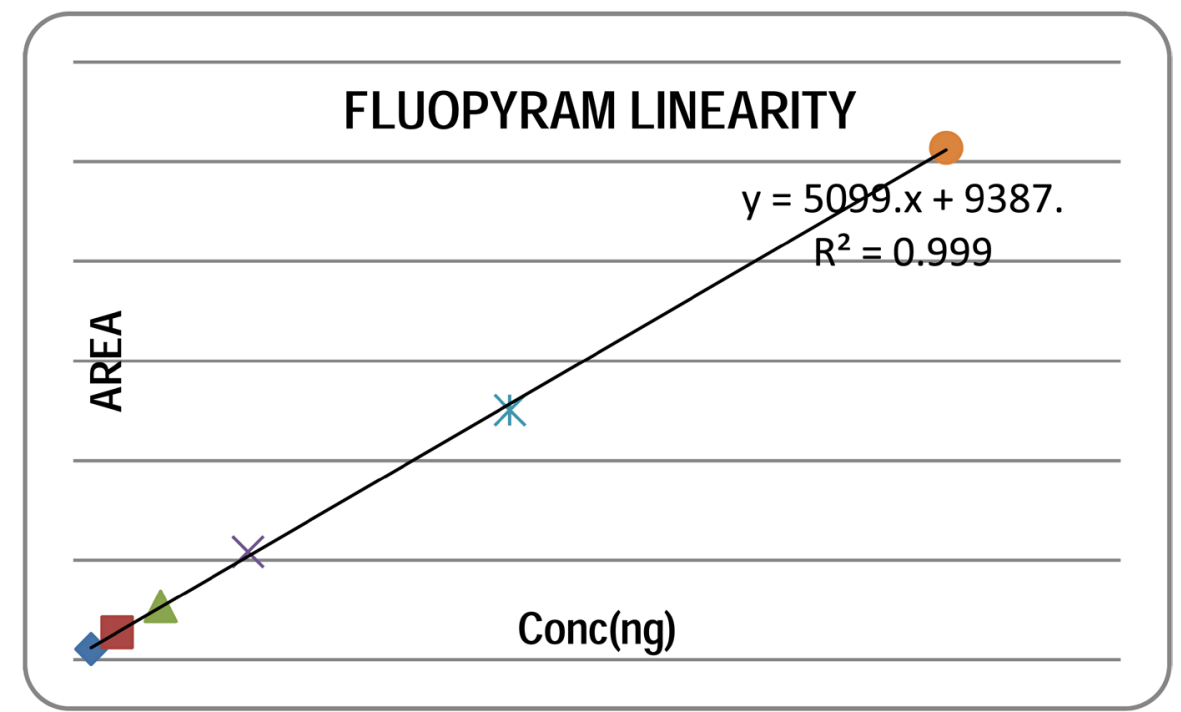

Figure 1. Linearity of fluopyram.

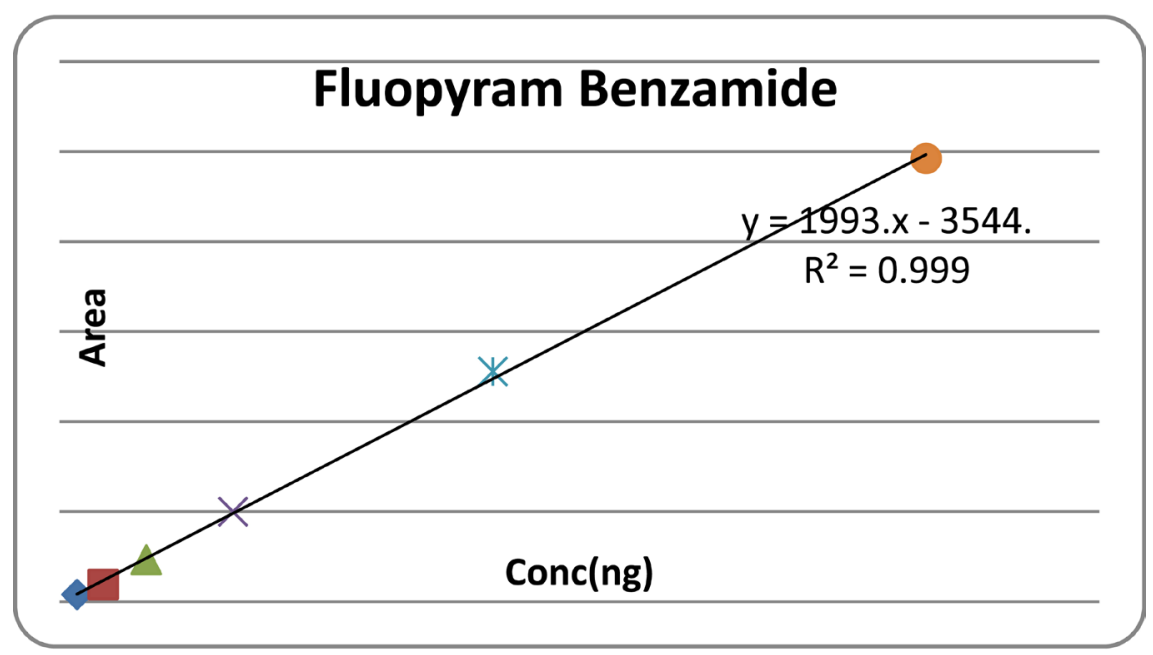

Figure 2. Linearity of fluopyram benzamide.

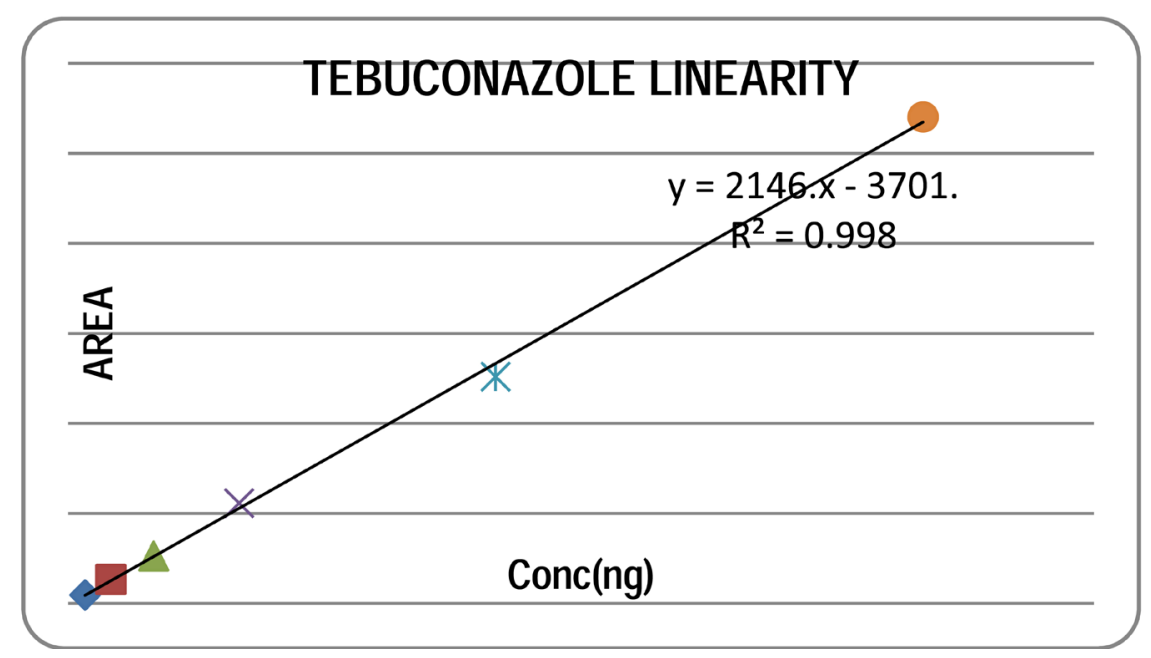

Figure 3. Linearity of tebuconazole. 
Table 3. Recoveries of fluopyram, fluopyram benzamide and tebuconazole at various fortification levels in different matrices.

\begin{tabular}{ccccc}
\hline \multirow{2}{*}{ Matrix } & \multirow{2}{*}{ Fortification level } & \multicolumn{3}{c}{ Recovery (\%) } \\
\cline { 3 - 5 } & & Fluopyram & Fluopyram Benzamide & Tebuconazole \\
\hline \multirow{2}{*}{ Immature fruits } & $0.05 \mathrm{mg} / \mathrm{kg}$ & $106.66(3.095)$ & $88.0(3.770)$ & $114.0(0.949)$ \\
& $0.25 \mathrm{mg} / \mathrm{kg}$ & $83.46(2.635)$ & $87.73(0.652)$ & $95.46(2.457)$ \\
& $0.50 \mathrm{mg} / \mathrm{kg}$ & $102.53(3.095)$ & $102.0(4.507)$ & $117.2(1.628)$ \\
\multirow{2}{*}{ Juice } & $0.05 \mathrm{mg} / \mathrm{kg}$ & $102.0(2.156)$ & $88.0(2.099)$ & $112.60(4.416)$ \\
& $0.25 \mathrm{mg} / \mathrm{kg}$ & $85.6(2.662)$ & $96.26(2.325)$ & $94.80(1.977)$ \\
& $0.50 \mathrm{mg} / \mathrm{kg}$ & $99.53(3.796)$ & $107.13(0.882)$ & $115.00(0.822)$ \\
\multirow{2}{*}{ Soil } & $0.05 \mathrm{mg} / \mathrm{kg}$ & $103.33(1.631)$ & $96.0(5.137)$ & $114.0(2.247)$ \\
& $0.25 \mathrm{mg} / \mathrm{kg}$ & $84.53(1.719)$ & $96.4(2.131)$ & $102.8(13.129)$ \\
& $0.50 \mathrm{mg} / \mathrm{kg}$ & $106.13(3.247)$ & $105.86(0.372)$ & $117.13(1.593)$ \\
\hline
\end{tabular}

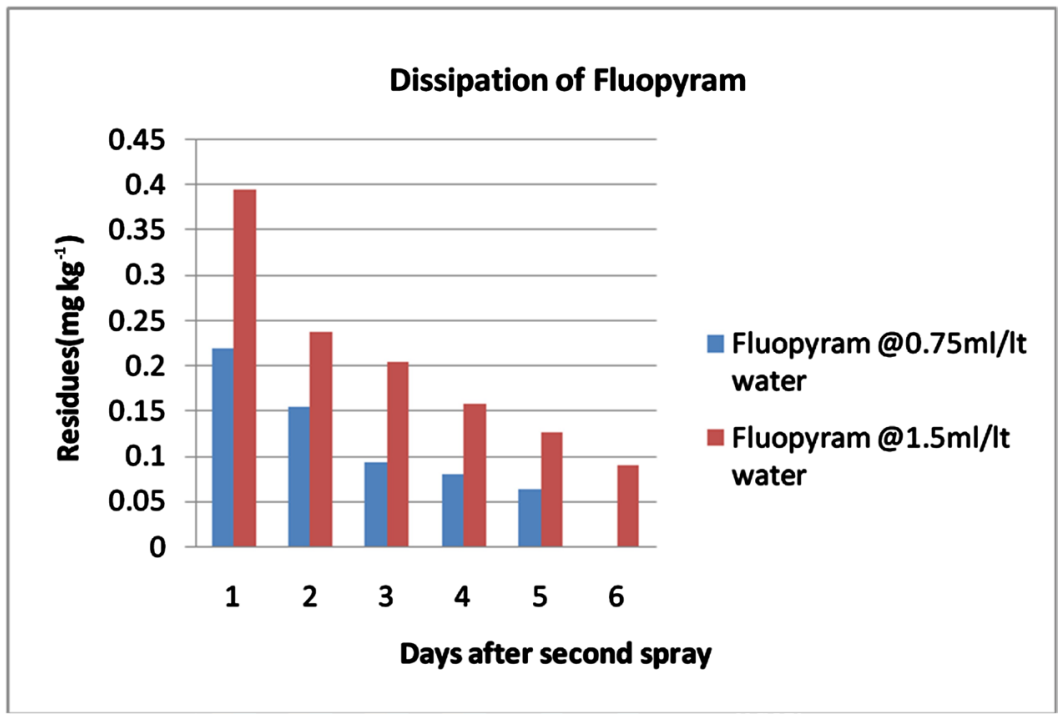

Figure 4. Dissipation pattern of fluopyram in/on pomegranate.

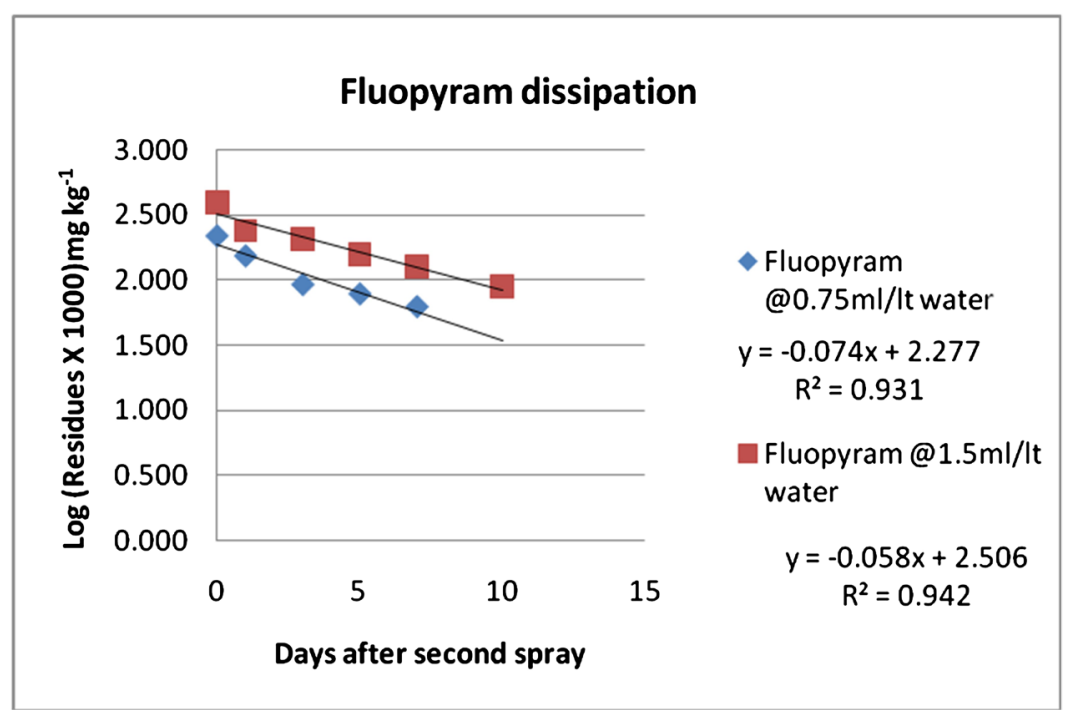

Figure 5. Semi logarithmic graph showing dissipation kinetics of fluopyram in pomegranate. 


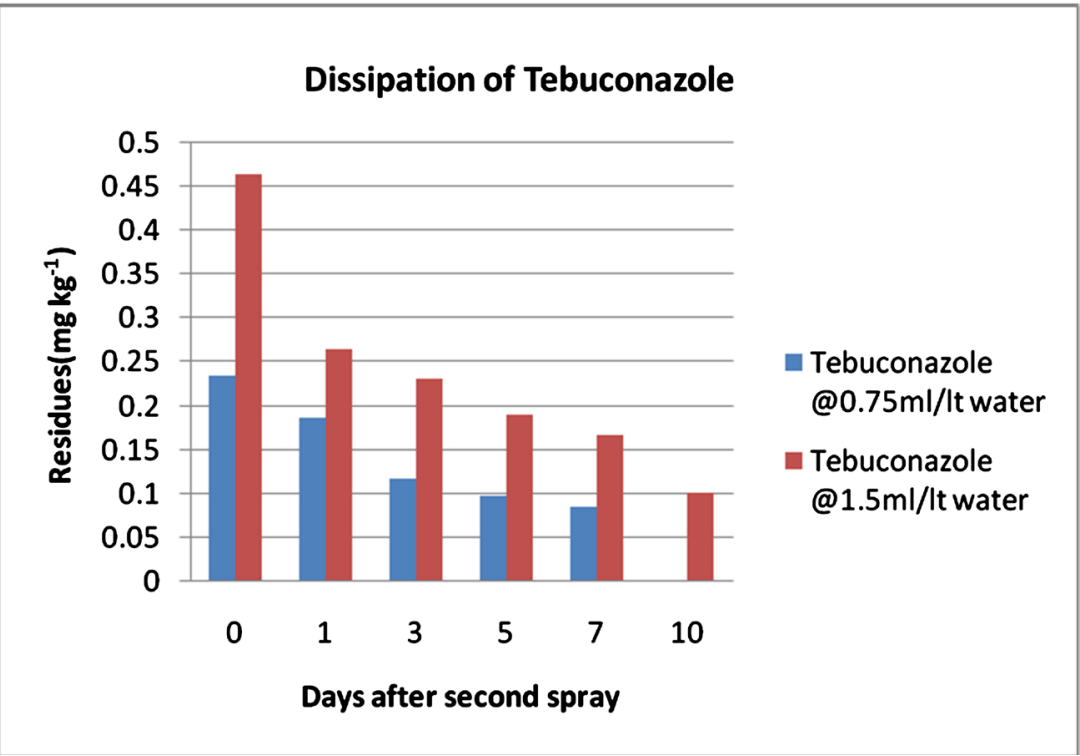

Figure 6. Dissipation pattern of tebuconazole in/on pomegranate.

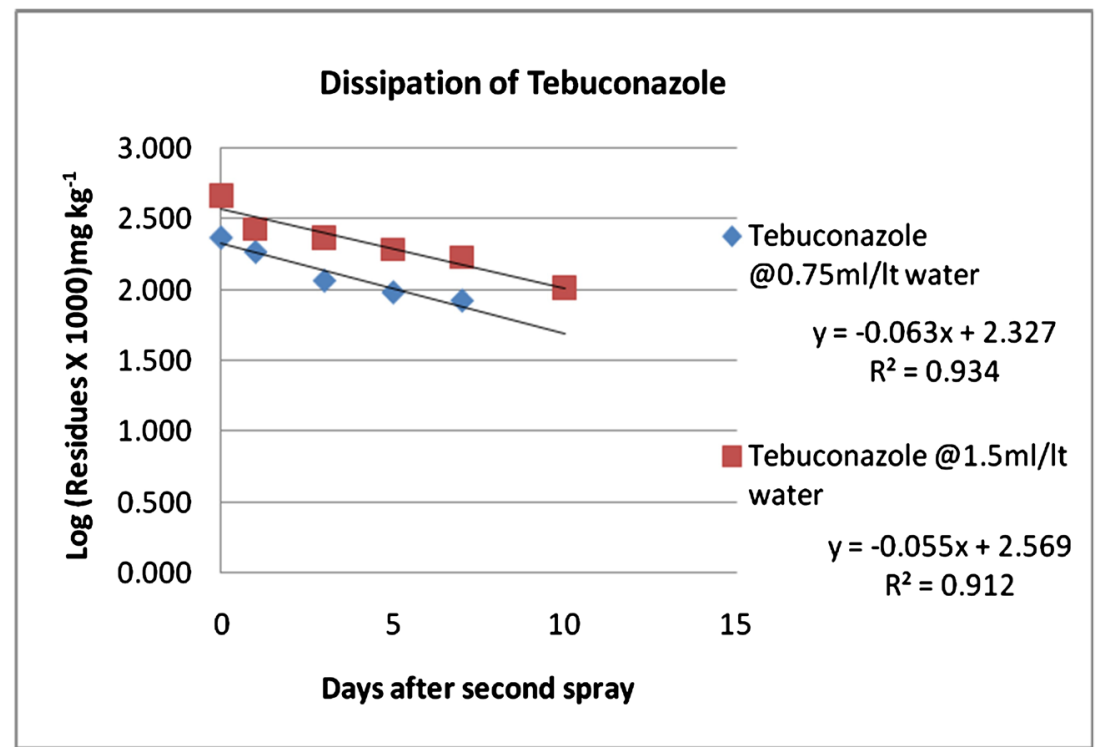

Figure 7. Semi logarithm graph showing dissipation kinetics of tebuconazole in/on pomegranate.

after the second application. Dissipation followed a linear trend with gradual degradation. The residue reached 0.063 and $0.089 \mathrm{mg} \mathrm{kg}^{-1}$ on $7^{\text {th }}$ and $10^{\text {th }}$ day, respectively on recommended and double dose. In mature fruits of pomegranate and juice, the residues of fluopyram were below quantitation limit (BQL) of 0.05 $\mathrm{mg} \mathrm{kg}^{-1}$. The residues of fluopyram were also estimated in oil at harvest which was below quantitation limit of $0.05 \mathrm{mg} / \mathrm{kg}$ in both the doses. As regards fluopyram benzamide, samples of immature fruits, mature fruits, juice and soil did not record any residues in recommended and double dose. They were below Quantitation limit of $0.05 \mathrm{mg} \mathrm{kg}^{-1}$.

The dissipation of tebuconazole also followed similar pattern of degradation. 
Table 4. Dissipation of fluopyram and tebuconazole in pomegranate fruits, edible aril, juice and soil.

\begin{tabular}{|c|c|c|c|c|c|c|}
\hline \multirow{3}{*}{$\begin{array}{l}\text { Days after } 2^{\text {nd }} \\
\text { Application }\end{array}$} & \multicolumn{6}{|c|}{ Residues of Fluopyram (mg/kg) } \\
\hline & \multicolumn{2}{|c|}{ Fluopyram } & \multicolumn{2}{|c|}{ Fluopyram benzamide } & \multicolumn{2}{|c|}{ Tebuconazole } \\
\hline & $\begin{array}{c}\text { Recommended } \\
\text { Dose } \\
(0.75 \mathrm{~g} / \mathrm{L})\end{array}$ & $\begin{array}{c}\text { Double } \\
\text { Recommended } \\
\text { Dose }(1.5 \mathrm{~g} / \mathrm{L})\end{array}$ & $\begin{array}{c}\text { Recommended } \\
\text { Dose } \\
(0.75 \mathrm{~g} / \mathrm{L})\end{array}$ & $\begin{array}{l}\text { Recommended } \\
\text { Dose }(1.5 \mathrm{~g} / \mathrm{L})\end{array}$ & $\begin{array}{l}\text { Recommended } \\
\text { Dose }\end{array}$ & $\begin{array}{c}\text { Recommended } \\
\text { Dose }\end{array}$ \\
\hline Pomegranate fruits & $\begin{array}{l}\text { Mean } \\
\text { SD ( } \pm)\end{array}$ & $\begin{array}{l}\text { Mean } \\
\text { SD ( } \pm)\end{array}$ & $\begin{array}{l}\text { Mean } \\
\text { SD ( }( \pm)\end{array}$ & $\begin{array}{l}\text { Mean } \\
\text { SD ( } \pm)\end{array}$ & $\begin{array}{l}\text { Mean } \\
\text { SD ( } \pm)\end{array}$ & $\begin{array}{l}\text { Mean } \\
\text { SD ( } \pm)\end{array}$ \\
\hline 0 Day & $\begin{array}{c}0.219 \\
(0.046)\end{array}$ & $\begin{array}{c}0.395 \\
(0.085)\end{array}$ & BQL & BQL & $\begin{array}{c}0.234 \\
(0.048)\end{array}$ & $\begin{array}{c}0.465 \\
(0.079)\end{array}$ \\
\hline 1 Day & $\begin{array}{c}0.154 \\
(0.039)\end{array}$ & $\begin{array}{c}0.238 \\
(0.062)\end{array}$ & $\mathrm{BQL}$ & $\mathrm{BQL}$ & $\begin{array}{c}0.186 \\
(0.050)\end{array}$ & $\begin{array}{c}0.266 \\
(0.071)\end{array}$ \\
\hline 3 Days & $\begin{array}{c}0.093 \\
(0.037)\end{array}$ & $\begin{array}{c}0.205 \\
(0.006)\end{array}$ & BQL & $\mathrm{BQL}$ & $\begin{array}{c}0.117 \\
(0.037)\end{array}$ & $\begin{array}{c}0.232 \\
(0.011)\end{array}$ \\
\hline 5 Days & $\begin{array}{c}0.079 \\
(0.002)\end{array}$ & $\begin{array}{c}0.157 \\
(0.035)\end{array}$ & BQL & BQL & $\begin{array}{c}0.097 \\
(0.015)\end{array}$ & $\begin{array}{c}0.191 \\
(0.042)\end{array}$ \\
\hline 7 Days & $\begin{array}{c}0.063 \\
(0.002)\end{array}$ & $\begin{array}{c}0.126 \\
(0.018)\end{array}$ & BQL & BQL & $\begin{array}{c}0.085 \\
(0.003)\end{array}$ & $\begin{array}{c}0.168 \\
(0.003)\end{array}$ \\
\hline 10 Days & $\mathrm{BQL}$ & $\begin{array}{c}0.089 \\
(0.005)\end{array}$ & BQL & BQL & $\mathrm{BQL}$ & $\begin{array}{c}0.102 \\
(0.018)\end{array}$ \\
\hline 15 Days & $\mathrm{BQL}$ & $\mathrm{BQL}$ & BQL & BQL & $\mathrm{BQL}$ & BQL \\
\hline Edible aril at harvest & $\mathrm{BQL}$ & BQL & BQL & $\mathrm{BQL}$ & $\mathrm{BQL}$ & BQL \\
\hline Juice at harvest & $\mathrm{BQL}$ & $\mathrm{BQL}$ & $\mathrm{BQL}$ & BQL & $\mathrm{BQL}$ & $\mathrm{BQL}$ \\
\hline Soil at harvest & BQL & BQL & BQL & BQL & BQL & BQL \\
\hline Regression equation & $\begin{array}{c}y=-0.0745 x+ \\
2.277\end{array}$ & $\begin{array}{c}y=-0.058 x+ \\
2.5069\end{array}$ & & & $\begin{array}{c}y=-0.0634 x+ \\
2.3276\end{array}$ & $\begin{array}{c}y=-0.0555 x+ \\
2.5693\end{array}$ \\
\hline Regression coefficient & $\mathrm{R}^{2}=0.931$ & $\mathrm{R}^{2}=0.942$ & & & $\mathrm{R}^{2}=0.9348$ & $\mathrm{R}^{2}=0.9125$ \\
\hline Half life (Days) & 4.04 & 5.18 & & & 4.75 & 5.42 \\
\hline PHI (Days) & 7.76 & 13.90 & & & 9.91 & 15.68 \\
\hline
\end{tabular}

LOQ: Fluopyram- $0.05 \mathrm{mg} / \mathrm{kg}$, Fluopyram benzamide- $0.05 \mathrm{mg} / \mathrm{kg}$ Tebuconazole- $-0.05 \mathrm{mg} / \mathrm{kg}$ Figureures in parenthesis are $\pm \mathrm{SD}$ values.

Initial residue levels of 0.234 and $0.465 \mathrm{mg} / \mathrm{kg}$ were detected in immature fruits of pomegranate. The residues gradually degraded and reached 0.085 and 0.102 $\mathrm{mg} / \mathrm{kg}$ in recommended and double dose, respectively on $7^{\text {th }}$ and $10^{\text {th }}$ day after second application. However, the residues were below quantitation limit of 0.05 $\mathrm{mg} / \mathrm{kg}$ in mature pomegranate fruits and juice and also soil at harvest. In the present study, both fluopyram and tebuconazole showed first order kinetics for dissipation and followed linear degradation pattern. Half life was calculated from dissipation pattern curves of first order kinetics. The results in respect of dissipation of fluopyram cannot be compared due to lack of literature. The dissipation of residues of fluopyram and tebuconazole (Luna Experience 400SC) was studied in chilli [7], onion [8] and watermelon [9] and tebuconazole alone applied in/on onion [10] [11], mango [12], ginseng [13], chilli [14], tomato [15] and apple [16]. 
According to Patel et al. 2016 [7], half life of fluopyram was 8.85 and 9.12 days, respectively in recommended and double dose. Dong and $\mathrm{Hu}, 2014$ [9] showed half life of 6.48 days for fluopyram in watermelon. In chilli, Saha, 2016 [7] found a half life of 1.161 and 1.241 days for single (100 g a.i./ha) and double (200 g a.i./ha) application rate.

For tebuconazole, half life of 6.69 and 7.72 days was reported in onion [8] and 0.866 and 1.083 days in case of chilli [7] at the single and double dose, respectively. In other studies, the reported half life was 1.7 days and 6 days in onion [11] and mango [12], 5.87 and 6.93 days in watermelon [9], 4.49 days in ginseng [13], 1 day in chilli [14] and 0.9 days in tomato [15]. However, half life of tebuconazole ranged between 19.38 and 25.99 days and 19.84 and 28.86 days at the application rate of 200 and $400 \mathrm{~g}$ ai/ha in apple [16].

A PHI of 21 days was recorded for tebuconazole on onion by CIB \& RC of India [2]. Mohopatra et al. 2014 [11] suggested a PHI of 16 days and 35 days for tebuconazole at 187.5 and $375 \mathrm{~g}$ a.i./ha in immature onion bulb with leaves. From the present study, the pre harvest interval (PHI) of 7.76 and 9.91 days for fluopyram and tebuconazole can be considered safe for harvesting residue free pomegranate at application rate of 75 and $150 \mathrm{~g}$ a.i./ha.

\section{Conflicts of Interest}

The authors declare no conflicts of interest regarding the publication of this paper.

\section{References}

[1] Anonymous (2017) Horticulture Statistics at a Glance 2017.

[2] http://cibrc.nic.in/mup.htm

[3] Baig, S.A., Akhtera, N.A., Ashfaq, M. and Rafique, M.A. (2009) Determination of the Organophosphorus Pesticide in Vegetables by High Performance Liquid Chromatography. American-Eurasian Journal of Agricultural \& Environmental Sciences, 6, 513-519.

[4] Khay, J.H., Choi, A.M., Abd El-Aty, M.I.R., Mamun, B.J., Park, A., Goudah, H.C. and Shin, J.H. (2008) Dissipation Behavior of Lufenuron, Benzoyl Phenyl Urea Insecticide in/on Chinese Cabbage Applied by Foliar Spraying under Greenhouse Condition. Bulletin of Environmental Contamination and Toxicology, 3, 369-372. https://doi.org/10.1007/s00128-008-9490-x

[5] Lehotay, S.J. (2005) Validation of a Fast and Easy Method for the Determination of Residues from 229 Pesticides in Fruits and Vegetables and Using Gas and Liquid Chromatography and Mass Spectrometric Detection. Journal-Association of Official Analytical Chemists, 88, 559-614.

[6] SANCO (2011) Method Validation and Quality Control Procedures for Pesticide Residue Analysis in Food and Feed. Document No. 12495/2011.

[7] Saha, S., Jadhav, M.R., Shabeer, T.P.A., Banerji, K., Sharma, B.K., Loganathan, M. and Rai, A.B. (2016) Safety Assessment and Bioefficacy of Fluopyram 20\% and Tebuconazole 20\% 40 SC in Chilli, Capsicum Annum L against Anthracnose Disease. Proceedings of the National Academy of Sciences, India, Section B: Biological Sciences, 86, 359-366. https://doi.org/10.1007/s40011-014-0450-4 
[8] Patel, B.V., Chawla, S., Gor, H., Upadhyay, P., Parmar, K.D., Patel, A.R. and Shah, P.G. (2016) Residue Decline and Risk Assessment of Fluopyram + Tebuconazole (400SC) in/on Onion (Allium cepa). Environmental Science and Pollution Research, 23, 20871-20881. https://doi.org/10.1007/s11356-016-7331-8

[9] Dong, B. and Hu, J. (2014) Dissipation and Determination of Fluopyram and Tebuconazole Residues in Watermelon and Soil by GCMS. International Journal of Environmental Analytical Chemistry, 94, 493-505.

https://doi.org/10.1080/03067319.2013.841152

[10] Mohapatra, S., Deepa, M. and Jagdish, G.K. (2011) Residue Study of Tebuconazole and Quinalphos on Onion. Bulletin of Environmental Contamination and Toxicology, 87, 703-707. https://doi.org/10.1007/s00128-011-0403-z

[11] Mohapatra, S. (2014) Persistence and Dissipation Kinetics of Trifloxystrobin and Tebuconazole in Onion and Soil. Journal of Environmental Science and Health, Part B, 49, 513-520. https://doi.org/10.1080/03601234.2014.896674

[12] Mohapatra S. (2015) Residue Levels and Dissipation Behaviours for Trifloxystrobin and Tebuconazole in Mango Fruit and Soil. Environmental Monitoring and Assessment, 187, 95. https://doi.org/10.1007/s10661-015-4324-x

[13] Wang, Y., Wang, C., Gao, J., Liu, C., Cui, L. and Li, A. (2015) Dissipation, Residues, and Safety Evaluation of Trifloxystrobin and Tebuconazole on Ginseng and Soil. Environmental Monitoring and Assessment, 187, 344. https://doi.org/10.1007/s10661-015-4591-6

[14] Sahoo, S.K., Jyot, G., Batto, R.S. and Singh, B. (2012) Dissipation Kinetics of Trifloxystrobin and Tebuconazole on Chilli and Soil. Bulletin of Environmental Contamination and Toxicology, 88, 368-371. https://doi.org/10.1007/s00128-011-0464-z

[15] Singh, G. and Singh, B. (2014) Residue Dynamics and Risk Assessment of Trifloxystrobin and Tebuconazole on Tomato (Lycopersicon esculentum mill.). American Journal of Environmental Protection, 2, 59-63. https://doi.org/10.12691/env-2-3-2

[16] Patyal, S.K., Sharma, I.D., Chandel, R.S. and Dubey, S.K. (2013) Dissipation Kinetics of Trifloxystrobin and Tebuconazole on Apple (Malus domestica) and Soil-A North Location Study from North Western Himalayan Region. Chemosphere, 92, 949-954. https://doi.org/10.1016/j.chemosphere.2013.02.069 